\title{
Response of Growth and Grazing Rate of Nanoflagellates on Synechococcus spp. to Experimental Nutrient Enrichment
}

\author{
An-Yi Tsai ${ }^{1,2, *}$ and Vladimir Mukhanov ${ }^{3}$ \\ 1 Institute of Marine Environment and Ecology, National Taiwan Ocean University, Keelung 202-24, Taiwan \\ 2 Center of Excellence for the Oceans, National Taiwan Ocean University, Keelung 202-24, Taiwan \\ 3 A.O. Kovalevsky Institute of Biology of the Southern Seas, Russian Academy of Sciences, \\ 229011 Sevastopol, Russia; v.s.mukhanov@ibss-ras.ru \\ * Correspondence: anyitsai@mail.ntou.edu.tw; Tel.: +886-2-2462-2192 (ext. 5705)
}

Citation: Tsai, A.-Y.; Mukhanov, V. Response of Growth and Grazing Rate of Nanoflagellates on

Synechococcus spp. to Experimental Nutrient Enrichment. Water 2021, 13, 2686. https://doi.org/10.3390/ w13192686

Academic Editor:

Alessandro Bergamasco

Received: 25 August 2021

Accepted: 25 September 2021

Published: 28 September 2021

Publisher's Note: MDPI stays neutral with regard to jurisdictional claims in published maps and institutional affiliations.

Copyright: (C) 2021 by the authors. Licensee MDPI, Basel, Switzerland. This article is an open access article distributed under the terms and conditions of the Creative Commons Attribution (CC BY) license (https:// creativecommons.org/licenses/by/ $4.0 /)$.

\begin{abstract}
As important bacterivores in planktonic food webs, mixotrophic nanoflagellates cancause mortality in marine Synechococcus spp. Our previous study found that the pigmented nanoflagellate (PNF) has a significant grazing impact on Synechococcus spp. In the current study, we applied the dilution approach to test the growth and grazing rates of nanoflagellates on Synechococcus spp. We then compared the differences between experimental nutrient additions and in situ conditions in the coastal waters of the East China Sea during the summer season from July to September. The growth rates of Synechococcus spp. in the ambient environment were between 0.54 and 0.62 day $^{-1}$, which were slightly higher than the 0.56 and 0.66 day $^{-1}$ with nutrient enrichment in summer. In contrast, our nutrient enrichment experiments produced a marked decline approximately from $21 \%$ to $58 \%$ in the nanoflagellate grazing rate on Synechococcus spp. The reason was that the mixotrophic PNFs directly used the added nutrients and reduced their supply of nutrients from prey during the incubation experiments.
\end{abstract}

Keywords: Synechococcus spp.; nanoflagellates; growth rate; grazing rate

\section{Introduction}

Synechococcus spp. is a genus of cyanobacteria that lives in coastal environments and is responsible for primary production [1]. Generally, Synechococcus are the numerically dominant picophytoplankton [2,3], and the dynamics of Synechococcus abundance are therefore of importance for our understanding of the microbial food web. Some previous studies demonstrate the importance of the grazing mortality of marine Synechococcus, of which daily removal rate of Synechococcus assemblage could be as high as $50 \%[4,5]$. Hence, it is apparent that grazing is critical in the marine food webs and provides energy to the higher trophic levels.

Although grazing by heterotrophic nanoflagellates is showed by top-down control in the bacterial communities, pigmented nanoflagellates (PNFs) have been considered as important bacterivores in planktonic food webs in recent studies [6-8]. Some field studies observed that in marine and freshwater systems, PNFs outnumber the heterotrophic nanoflagellates, and thus have a greater grazing impact on the bacterial community [6,8-10]. PNFs can survive in different environments by relying on bacterivory during low-light conditions, darkness, dissolved nutrient concentration, and photosynthesis when prey concentration is low [11-14].

The important role of pigmented nanoflagellatesas important bacterial consumers has been demonstrated in previous studies $[6,8]$, but their significance in regulating bacterial communities is still under discussion. PNFs are also important Synechococcus grazers in marine environments [15]. Our previous findings showed a significant impact of PNF grazing on Synechococcus [16]. This finding has provided new data for estimating the impact of grazing on Synechococcus and the importance of PNF in a marine ecosystem. 
Our results showed that the nutrient concentrations were low during warm seasons [3]. Therefore, with their smaller cell sizes and high surface area to volume ratio, Synechococcus can take up nutrients more efficiently than PNFs. As PNFs cannot successfully compete with Synechococcus under these conditions, we suggested that PNFs employ phagotrophic behaviors as a means to obtain extra supplemental nutrients.

Other field studies suggested that resources (inorganic nutrients) and temperature are the two primary factors limiting the growth of Synechococcus [17-19]. Moreover, the growth of phytoplankton and Synechococcus in warmer seasons is seemingly controlled by the availability of nutrients (also referred to as bottom-up control) $[17,18]$. Considering this significant control role of inorganic nutrients on Synechococcus growth in warmer seasons, some studies reported higher growth rates of Synechococcus in nutrient-enriched incubations $[20,21]$. We believe that nutrient supply accelerates the growth rates of Synechococcus. However, the effects of PNF grazing rates under nutrient enrichment have rarely been elucidated [22]. Here, we hypothesize that the nanoflagellate grazing rates on Synechococcus would increase due to the greater abundance and growth rates of Synechococcus in nutrientenriched incubations. In this study, we tested the response of growth and nanoflagellate grazing rates on Synechococcus to experimental nutrient additions in dilution experiments in coastal waters of the western subtropical Pacific Ocean during the summer of 2020.

\section{Material and Methods}

\subsection{Study Sites and Samplings}

Samples were collected using a bucket on 5 and 29 July, 10 August, and 17 September 2020 from the surface waters at an established station, which is located in coastal waters off the Northeastern Taiwan coast $\left(25^{\circ} 09^{\prime} 06^{\prime \prime} \mathrm{N}, 121^{\circ} 46^{\prime} 38.5^{\prime \prime} \mathrm{E}\right)$. Seawater was collected on each sampling day from 09:00 to 10:00 in the morning (local time) for dilution experiments. Water temperature was taken at the time of casting. The zooplankton-free whole water was obtained by gently siphoning the seawater through a $200 \mu \mathrm{m}$ mesh immediately into acidcleaned $10 \mathrm{~L}$ polypropylene carboys, which were rinsed with $10 \% \mathrm{HCl}$ and Milli-Q water. All samples were deposited in the lab within $30 \mathrm{~min}$ of sampling. Nutrient concentrations were measured with a custom-made flow injection analyzer with phosphate $\left(\mathrm{PO}_{4}\right)$ and nitrate $\left(\mathrm{NO}_{3}\right)$ detection limits of 0.03 and $1.5 \mu \mathrm{mol} \mathrm{L}{ }^{-1}$, respectively [23].

\subsection{Incubation Experiments}

A major objective of this study was to understand the effects of experimental nutrient additions on growth and nanoflagellate grazing rates on Synechococcus. We estimated these rates using a dilution technique following the method described by Landry and Hasset [24]. Samples were size-fractionated by filtration. We used a $10 \mu \mathrm{m}$ Nuclepore filter to remove microzooplankton, and a $0.2 \mu \mathrm{m}$ Nuclepore filter pore with low pressure $(<100 \mathrm{~mm} \mathrm{Hg})$ to remove the remaining planktonic organisms, including the bacteria. Additionally, we chose the size fractionation for grazers $(<10 \mu \mathrm{m})$ based on our previous study, and eliminated ciliates, except for nanoflagellates [6]. The $10 \mu \mathrm{m}$ filtrates were diluted in the $0.2 \mu \mathrm{m}$ filtrate in a four-point dilution series: $25,50,75$, and $100 \%$ of the $10 \mu \mathrm{m}$ filtered seawater sample. Furthermore, each dilution was poured into triplicates in $500 \mathrm{~mL}$ acid-washed polycarbonate bottles. The final concentrations of the nutrients were $20 \mu \mathrm{mol} \mathrm{L}{ }^{-1} \mathrm{NO}_{3}$ and $2 \mu \mathrm{mol} \mathrm{L}{ }^{-1} \mathrm{PO}_{4}$ before added to these bottles. Another dilution series was prepared with no added nutrients, and the difference of growth and nanoflagellate grazing on Synechococcus was compared between these two (nutrient-enriched and in situ condition) treatments. The samples were placed in a water bath under natural light for $24 \mathrm{~h}$ and were made in triplicates. Synechococcus abundance $\left(\mathrm{Nt}_{0} ; \mathrm{N}_{\mathrm{t} 24}\right)$ was estimated based on the subsamples $(50 \mathrm{~mL})$ taken at the beginning $\left(\mathrm{t}_{0}\right)$ and $24 \mathrm{~h}\left(\mathrm{t}_{24}\right)$ after the incubation. The net growth rate of Synechococcus $\left(\mathrm{k}\right.$, day $\left.{ }^{-1}\right)$ was calculated as $\mathrm{k}=\left(\mathrm{lnN}_{\mathrm{t} 24}-\operatorname{lnNt}_{0}\right) / \mathrm{t}$, where $\mathrm{t}$ is the incubation time ( $24 \mathrm{~h}$ ), and $\mathrm{N}_{\mathrm{t} 24}$ and $\mathrm{Nt}_{0}$ are the Synechococcus abundance at the end and the start of the experiments, respectively. In the linear regression of the observed net growth rates versus dilution, $\mu$ is the y-intercept of the regression and a direct estimate 
of grazing rates $(\mathrm{g})$ of nanoflagellates from the slope of the regression line. The growth $(\mu)$ and nanoflagellate grazing rates $(\mathrm{g})$ on Synechococcus were estimated based on the linear regression.

We used an epifluorescence microscope (NikonOptiphot-2) $(1000 \times)$ to count the Synechococcus and nanoflagellate abundance. After we placed the subsamples of 1-2 $\mathrm{mL}$ or $20 \mathrm{~mL}$ onto $0.2 \mu \mathrm{m}$ or $0.8 \mu \mathrm{m}$ black Nuclepore filters for Synechococcus and nanoflagellates, we stained the samples with DAPI at a final concentration of $1 \mu \mathrm{g} \mathrm{mL} L^{-1}$ [25] to count heterotrophic (nonpigmented) nanoflagellates (HNF). A separate filter set optimized for chlorophyll or DAPI was used to count the PNFs and HNFs based on the absence or presence of chlorophyll autofluorescence. Under UV illumination, HNFs were in blue fluorescence, and under blue excitation light, PNFs and Synechococcus were in red and orange autofluorescence, respectively.

\subsection{Statistical Analysis}

Least-squares regression analysis was performed to analyze the relationship between Synechococcus net growth rate and fraction of $10 \mu \mathrm{m}$ filtered water in the ambient nutrients and nutrient enrichment experiments. Significance of the regression lines was tested using an analysis of variance (ANOVA). Moreover, the significance between both slopes was determined using an $F$ test. STATISTICA 7.0 (StatSoft Inc., Tulsa, OK, USA) software was used for all statistical operations, with a statistical significance level of $<0.05$.

\section{Results}

The in situ abundance of Synechococcus was observed between $3.2 \times 10^{4}$ and $6.2 \times 10^{4}$ cells mL ${ }^{-1}$ during the study periods. Heterotrophic (nonpigmented) and pigmented nanoflagellates abundance ranged from 1.8 to $2.8 \times 10^{3}$ cells $\mathrm{mL}^{-1}$ and 3.2 to $4.3 \times 10^{3}$ cells $\mathrm{mL}^{-1}$ at our study site, respectively. In the current study, we found that PNFs have more abundance than nonpigmented nanoflagellate communities, comprising about $60 \%$ of the total nanoflagellate population at our study site.

Figure 1 shows the estimates based on the dilution experiments for growth and grazing rate of nanoflagellates on Synechococcus with added nutrients and ambient nutrients. On the other hand, $\mathrm{NO}_{3}$ and $\mathrm{PO}_{4}$ concentrations in added nutrients and the ambient condition are shown in Table 1. The growth rates of Synechococcus ranged from 0.54 to $0.62 \mathrm{day}^{-1}$ and 0.56 to 0.66 day $^{-1}$ with ambient nutrients and nutrient enrichment experiments during the study periods, respectively (Figure 1, Table 1).

The observed effects of the experimental nutrient amendment on the grazing rates of nanoflagellates on Synechococcus were observed between 0.15 and 0.31 day $^{-1}$ in the summer (Table 1, Figure 1). Overall, the grazing rate of nanoflagellates on Synechococcus was significantly lower in nutrient-enriched treatments than in the in situ condition (Table 1); the grazing rate of nanoflagellatesin nutrient-enriched treatments decreased from about $21 \%$ to $58 \%$ compared to that in ambient conditions (Table 1 ). 


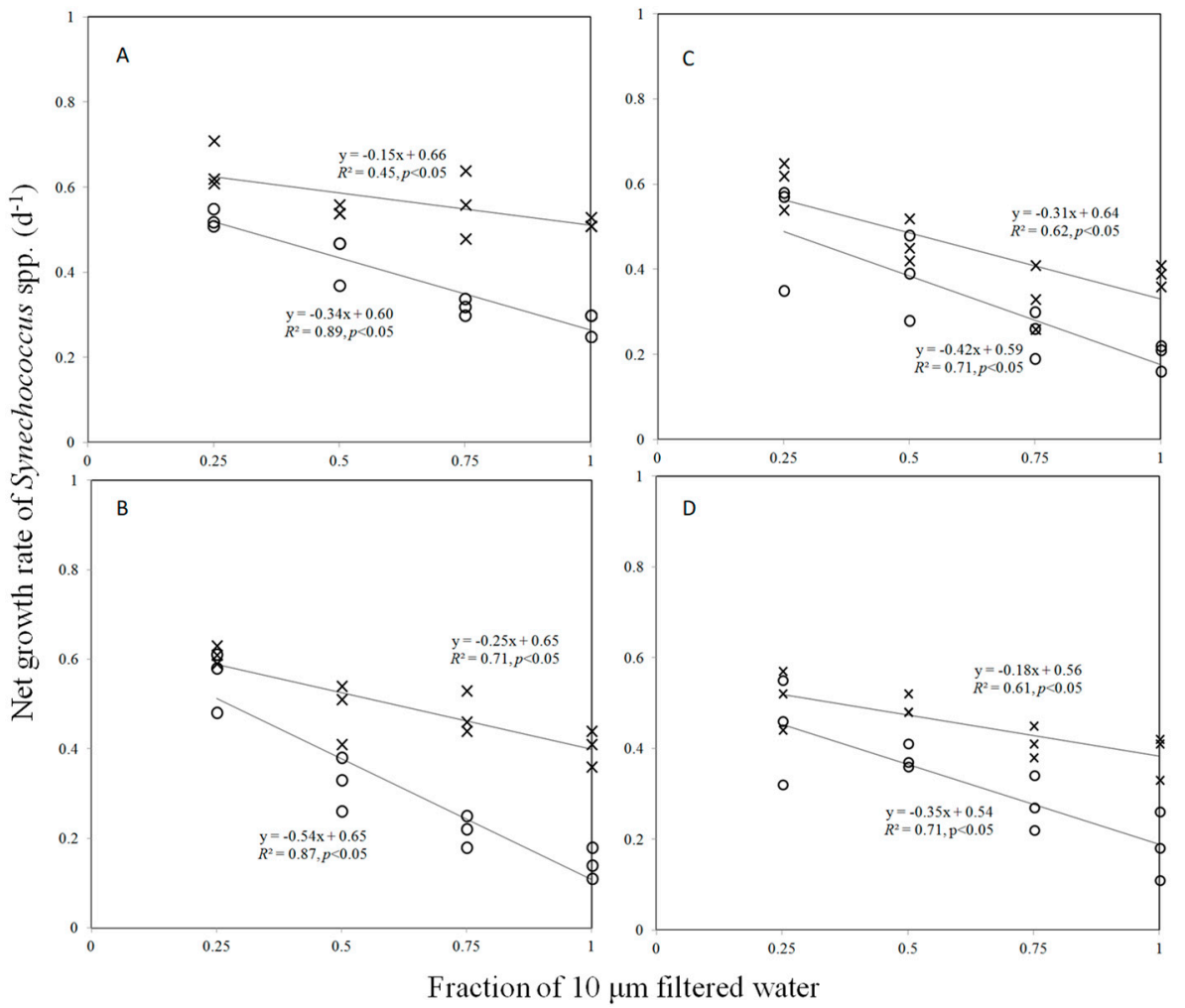

Figure 1. Dilution plots of Synechococcus spp. net growth rate $\left(\right.$ day $\left.^{-1}\right)$ versus the fraction of $10 \mu \mathrm{m}$ filtered water in early (A), the end of July (B), August (C), and September (D). Open circles and cross marks represent the net growth rates in the in situ condition and nutrient-enriched treatments, respectively.

Table 1. Surface in situ water temperature, nutrients at the sampling site, and enriched incubations at the beginning of experiments. Growth and nanoflagellate grazing rates upon Synechococcus spp. estimated by linear regression of dilution experiments under in situ and nutrient-enriched conditions conducted during the study period. ${ }^{\text {a: }}$ Percentage of difference of grazing rate between nutrient enriched and in situ condition.

\begin{tabular}{|c|c|c|c|c|c|c|}
\hline & Temperature & $\mathrm{NO}_{3}$ & $\mathrm{PO}_{4}$ & Growth Rate & Grazing Rate & $\begin{array}{c}\text { Decreased } \\
\text { Percentage of } \\
\text { Grazing Rate }^{\text {a }}\end{array}$ \\
\hline & $\left({ }^{\circ} \mathrm{C}\right)$ & $\left(\mu \mathrm{mol} \mathrm{L}{ }^{-1}\right)$ & $\left(\mu \mathrm{mol} \mathrm{L}{ }^{-1}\right)$ & $\left(\right.$ day $\left.^{-1}\right)$ & $\left(\right.$ day $\left.^{-1}\right)$ & \\
\hline 5 July & & & & & & \\
\hline In situ & 28.5 & 2.3 & 0.4 & 0.60 & 0.34 & \\
\hline $\begin{array}{l}\text { nutrient-enriched } \\
29 \text { July }\end{array}$ & & 19.4 & 1.9 & 0.66 & 0.15 & $56 \%$ \\
\hline In situ & 30 & 1.8 & 0.5 & 0.62 & 0.50 & \\
\hline $\begin{array}{l}\text { nutrient-enriched } \\
\text { August }\end{array}$ & & 18.6 & 1.8 & 0.65 & 0.21 & $58 \%$ \\
\hline In situ & 29 & 3.1 & 0.8 & 0.59 & 0.42 & \\
\hline nutrient-enriched & & 16.2 & 1.5 & 0.64 & 0.31 & $21 \%$ \\
\hline September & 28.5 & & & & & \\
\hline In situ & & 3.5 & 0.7 & 0.54 & 0.35 & \\
\hline nutrient-enriched & & 18.9 & 1.6 & 0.56 & 0.18 & $49 \%$ \\
\hline
\end{tabular}

\section{Discussion}

Synechococcus is an important part of the microbial food web and carbon flow. It is also well recognized that nanoflagellate grazing is an important top-down control for Synechococcus mortality, particularly in the summer in the western Pacific coastal 
region [3]. In this study, we experimentally exposed the same community to changes in the nanoflagellate grazing rates on Synechococcus after nutrient addition. The experimental results do not support our hypothesis that the nanoflagellate grazing rates on Synechococcus would increase due to the greater abundance and growth rates of Synechococcus in nutrientenriched incubations. Our results show that the grazing rate of PNFs on Synechococcus was significantly lower in nutrient-enriched treatments than in the in situ condition.

In the present study, the addition of nutrients into the experimental bottles only led to slightly increased growth rates of Synechococcus (Table 1). Similarly, Worden and Binder [5] noted that changes in the nitrogen and phosphorus contents did not have a significant effect on the growth rates of Synechocoscus. In the laboratory experiments on Synechococcus isolates, preference of $\mathrm{NH}_{4}$ over $\mathrm{NO}_{3}$ was observed [26]. In our previous study, we observed that viruses significantly affect the nutrient regeneration, and enhanced the growth rates in Synechococcus during the daytime in the subtropical western Pacific coastal waters [27]. Data from the previous studies indicated that viral-induced ammonium regeneration resulted in increased growth of Synechococcus $[28,29]$. The abovementioned results could explain the meager increase in the growth rates of Synechococcus in the nutrient-enriched bottles in this study.

Phytoplankton cells grazed by microzooplanktons vary in size from picophytoplankton to large cells [30]. However, at our study site, microzooplanktons (e.g., ciliates) could only remove 3\% of Synechococcus production [16]. Indeed, in this region, our study is the first to identify the dominant PNF populations in the nanoflagellate community and report that PNF dominated grazing on Synechococcus [16]. This finding proved that Synechococcus represents the transfer of carbon and nutrients to PNF through the microbial food web in our study site.

After nutrient addition, the grazing rate of PNFs on Synechococcus increases, which may be caused by the changes in the quality of the cyanobacteria available as food for grazers [16]. In contrast, the grazing rate of PNFs on Synechococcus in nutrient-enriched treatments decreased between $21 \%$ and $58 \%$, compared with that in the ambient condition in this study (Table 1). Some studies concluded that nutrient limitation might stimulate mixotrophic grazing in some environments [31,32]. Olrik [32] demonstrated that ingesting bacteria by mixotrophic Chrysophytes could limit their demand for phosphorus. Similarly, Tsai et al. [6] found that the PNF population ingested bacteria for phosphate supplement when soluble reactive phosphorus was low. In this study, we suggest that PNF used the added nutrients and reduced their feeding ability to supply themselves with nutrients from preys during the incubation experiments. A similar result was reported earlier in another nutrient-enriched experiment, wherein Sargasso Sea populations also caused a remarkable decline in phagotrophically active PNFs after adding phosphorus [22].

In most earlier dilution studies, nutrients were added to the bottles to prevent nutrient limitation of phytoplankton growth during incubation $[5,19,33]$. However, it is notable that the effects of nutrients on the grazing rates on picoplankton were different in the in situ conditions. In fact, the importance of Synechococcus consumers in nanoflagellate composition should be taken into consideration. In the case of PNF dominance, the grazing rate of PNFs on Synechococcus under nutrient-enriched incubations may be underestimated due to the reduced feeding ability of PNFs, similar to that observed in our study. Some studies were unable to assess the reason for so many non-significant grazing rates in their dilution experiments, and suggested varied factors, such as food selection and dilution effects on microzooplankton [34], as the cause for such a high portion of non-significant grazing estimates. The grazing impact of PNFs on Synechococcus under nutrient-enriched conditions was not considered in these field studies.

\section{Conclusions}

In summary, our study tested the Synechococcus growth and the grazing rates of nanoflagellates under conditions of with and without nutrient additions. The samples were collected from the coastal waters of the western subtropical Pacific Ocean during the 
summer season. The experimental results suggest that nutrient enrichment did not have a significant effect on the growth rates of Synechococcus. Furthermore, we suggest that in the summer season, as Synechococcus has great capacity to acquire regenerated nutrients at low concentrations, its growth rate is greatly affected. Overall, the grazing rate of PNFs on Synechococcus was significantly lower in nutrient-enriched treatments than that with ambient nutrients. In this situation, we speculate that the PNFs used the added nutrients and decreased their ability to supply themselves with nutrients from prey in the incubation experiments. The present study should guide future work towards understanding the functional roles of PNF in other environments.

Author Contributions: Conceptualization: A.-Y.T.; methodology: A.-Y.T.; validation: A.-Y.T.; formal analysis: A.-Y.T.; investigation: A.-Y.T.; resources: A.-Y.T.; data curation: A.-Y.T.; writing-original draft preparation: A.-Y.T. and V.M.; writing—review and editing: A.-Y.T. and V.M.; funding acquisition: A.-Y.T. and V.M. All authors have read and agreed to the published version of the manuscript.

Funding: The research was conducted in the frame of the Russian state assignment No. 1210406001786 and supported by RFBR project 21-55-52001, and the Ministry of Science and Technology, ROC (Taiwan), grant number NSC 109-2611-M-019-013.

Institutional Review Board Statement: The study was conducted according to the guidelines of the Declaration of Helsinki, and approved by the Institutional Review Board.

Informed Consent Statement: Not applicable.

Conflicts of Interest: The authors declare no conflict of interest.

\section{References}

1. Collier, J.L.; Palenik, B. Phycoerythrin-containing picoplankton in the Southern California Bight. Deep-Sea Res. II 2003, 50, 2405-2422. [CrossRef]

2. Agawin, N.S.R.; Duarte, C.M.; Agustí, S. Nutrient and temperature control of the contribution of picoplankton to phytoplankton biomass and production. Limnol. Oceanogr. 2000, 45, 591-600. [CrossRef]

3. Tsai, A.Y.; Chiang, K.P.; Chang, J.; Gong, G.C. Seasonal diel variations of picoplankton and nanoplankton in a subtropical Western Pacific coastal ecosystem. Limnol. Oceanogr. 2005, 50, 1221-1231. [CrossRef]

4. Sherr, E.B.; Sherr, B.F. Significance of predation by protists in aquatic microbial food webs. Antonie Van Leeuwenhoek. 2002, 81, 293-308. [CrossRef] [PubMed]

5. Worden, A.Z.; Binder, B.J. Application of dilution experiments for measuring growth and mortality rates among Prochlorococcus and Synechococcus populations in oligotrophic environments. Aquat. Microb. Ecol. 2003, 30, 159-174. [CrossRef]

6. Tsai, A.Y.; Gong, G.C.; Sanders, R.W.; Chen, W.H.; Chao, C.F.; Chiang, K.P. Importance of bacterivory by pigmented and heterotrophic nanoflagellates during the warm season in a subtropical western Pacific coastal ecosystem. Aquat. Microb. Ecol. 2011, 63, 9-18. [CrossRef]

7. Princiotta, S.D.; Smith, B.; Sanders, R.W. Temperature-dependent phagotrophy and phototrophy in a mixotrophic chrysophyte. J. Phycol. 2016, 52, 432-440. [CrossRef]

8. Princiotta, S.D.; Sanders, R.W. Heterotrophic and mixotrophic nanoflagellates in a mesotrophic lake: Abundance and grazing impacts across season and depth. Limnol. Oceanogr. 2017, 62, 632-644. [CrossRef]

9. Berninger, U.G.; Caron, D.A.; Sanders, R.W. Mixotrophic algae in three ice-covered lakes of the Pocono Mountains, U.S.A. Freshw. Biol. 1992, 28, 263-272. [CrossRef]

10. Domaizon, I.; Viboud, S.; Fontvieille, D. Taxonspecific and seasonal variations in flagellates grazing on heterotrophic bacteria in the oligotrophic Lake Annecy importance of mixotrophy. FEMS Microbiol. Ecol. 2003, 46, 317-329. [CrossRef]

11. Sanders, R.W. Mixotrophic protists in marine and freshwater ecosystems. J. Protozool. 1991, 38, 76-81. [CrossRef]

12. Holen, D.A. Effects of prey abundance and light intensity on the mixotrophic chrysophytePoterioochromonasmalhamensis from a mesotrophic lake. Freshw. Biol. 1999, 42, 445-455. [CrossRef]

13. Jones, R.I. Mixotrophy in planktonic protists: An overview. Freshw. Biol. 2000, 45, 219-226. [CrossRef]

14. Unrein, F.; Massana, R.; Alonso-Sáez, L.; Gasol, J.M. Significant year-round effect of small mixotrophic flagellates on bacterioplankton in an oligotrophic coastal system. Limnol. Oceanogr. 2007, 52, 456-469. [CrossRef]

15. Safi, K.A.; Hall, J.A. Mixotrophic and heterotrophic nanoflagellate grazing in the convergence zone east of New Zealand. Aquat. Microb. Ecol. 1999, 20, 33-93. [CrossRef]

16. Tsai, A.Y.; Chiang, K.P.; Chan, Y.F.; Lin, Y.C.; Chang, J. Pigmented nanoflagellates in the coastal western subtropical Pacific are important grazers on Synechococcus populations. J. Plank. Res. 2007, 29, 71-77. [CrossRef]

17. Chang, J.; Lin, K.H.; Chen, K.M.; Gong, G.C.; Chiang, K.P. Synechococcus growth and mortality rates in the East China Sea: Range of variations and correlation with environmental factors. Deep-Sea Res. 2003, 50, 1265-1278. [CrossRef] 
18. Tsai, A.Y.; Chiang, K.P.; Chang, J.; Gong, G.C. Seasonal variations in trophic dynamics of nanoflagellates and picoplankton in coastal waters of the western subtropical Pacific Ocean. Aquat. Microb. Ecol. 2008, 51, 263-274. [CrossRef]

19. Hirose, M.; Katano, T.; Nakano, S.I. Growth and grazing mortality rates of Prochlorococcus, Synechococcus and eukaryotic picophytoplankton in a bay of the Uwa Sea, Japan. J. Plank. Res. 2008, 30, 241-259. [CrossRef]

20. Moore, L.R.; Goericke, R.; Chisholm, S.W. Comparative physiology of Synechococcus and Prochlorococcus: Influence of light and temperature on growth, pigments, fluorescence and absorptive properties. Mar. Ecol. Prog. Ser. 1995, 116, 259-275. [CrossRef]

21. Agawin, N.S.; Duarte, C.M.; Agusti, S. Response of Mediterranean Synechococcus growth and loss rates to experimental nutrient inputs. Mar. Ecol. Prog. Ser. 2000, 206, 97-106. [CrossRef]

22. Olrik, K. Ecolgy of mixotrophic Eagellates with special reference to Chrysophyceae in Danish lakes. Hydrobiologia 1998, 369-370, 329-338. [CrossRef]

23. Gong, G.C.; Shiah, F.K.; Liu, K.K.; Wen, Y.H.; Liang, M.H. Spatial and temporal variation of chlorophyll a, primary productivity and chemical hydrography in the southern East China Sea. Cont. Shelf Res. 2000, 20, 411-436. [CrossRef]

24. Landry, M.R.; Hasset, R.P. Estimating the grazing impact of marine micro-zooplankton. Mar. Biol. 1982, 67, 283-288. [CrossRef]

25. Porter, K.G.; Feig, Y.S. The use of DAPI for identifying and counting aquatic microflora. Limnol. Oceanogr. 1980, 25, 943-948. [CrossRef]

26. Moore, L.R.; Post, A.F.; Rocap, G.; Chisholm, S.W. Utilization of different nitrogen sources by the marine cyanobacteria Prochlorococcus and Synechococcus. Limnol. Oceanogr. 2002, 47, 989-996. [CrossRef]

27. Tsai, A.Y.; Gong, G.C.; Chung, C.C.; Huang, Y.T. Different impact of nanoflagellate grazing and viral lysis on Synechococcus spp. and picoeukaryotic mortality in coastal waters. Estuar. Coast. Shelf Sci. 2018, 209, 1-6. [CrossRef]

28. Ayukai, T. Possible limitation of the dilution technique for estimating growth and grazing mortality rates of picoplanktonic cyanobacteria in oligotrophic tropical waters. J. Exp. Mar. Biol. Ecol. 1996, 198, 101-111. [CrossRef]

29. Tsai, A.Y.; Gong, G.C.; Huang, Y.W. Importance of the viral shunt in nitrogen cycling in Synechococcus spp. growth in subtropical western Pacific coastal waters. Terr. Atmos. Ocean. Sci. 2014, 6, 839-846. [CrossRef]

30. Zhou, L.B.; Tan, Y.H.; Huang, L.M.; Huang, J.; Liu, H.; Lian, X. Phytoplankton growth and microzooplankton grazing in the continental shelf area of north-eastern South China Sea after Typhoon Fengshen. Cont. Shelf Res. 2011, 31, 1663-1671. [CrossRef]

31. Hitchman, R.B.; Jones, H.L.J. The role of mixotrophic protists in the population dynamics of the microbial food web in a small artificial ponds. Freshw. Biol. 2000, 43, 231-241. [CrossRef]

32. Arenovski, A.L.; Lim, E.L.; Caron, D.A. Mixotrophic nanoplankton in oligotrophic surface waters of the Sargasso Sea may employ phagotrophy to obtain major nutrients. J. Plank. Res. 1995, 17, 801-820. [CrossRef]

33. Worden, A.Z.; Nolan, J.K.; Palenik, B. Assessing the dynamics and ecology of marine picophytoplankton: The importance of the eukaryotic component. Limnol. Oceanogr. 2004, 49, 168-179. [CrossRef]

34. Dolan, J.R.; Gallegos, C.L.; Moigis, A. Dilution effects on microzooplankton in dilution grazing experiments. Mar. Ecol. Prog. Ser. 2000, 200, 127-139. [CrossRef] 